\title{
lowa Farm Environmental Leaders' Perspectives on the U.S. Farm Bill Conservation Programs
}

\author{
Gabriel Medina ${ }^{1 * \dagger}$, Catherine Isley ${ }^{2 \dagger}$ and J. Arbuckle ${ }^{3 \dagger}$ \\ ${ }^{1}$ Department of Agronomy, University of Brasilia, Brasilia, Brazil, ${ }^{2}$ Division of Applied Social Sciences, University of Missouri, \\ Columbia, MO, United States, ${ }^{3}$ Department of Sociology, lowa State University, Ames, IA, United States
}

\section{OPEN ACCESS}

Edited by:

Alisa W. Coffin,

United States Department of Agriculture, United States

Reviewed by:

Christopher Edward Latimer, The Nature Conservancy,

United States

Alycia Rae Bean,

United States Department of

Agriculture, United States

*Correspondence:

Gabriel Medina

gabriel.medina@unb.br

TORCID:

Gabriel Medina

orcid.org/0000-0002-5815-6812

Catherine Isley

orcid.org/0000-0003-3431-1395

J. Arbuckle

orcid.org/0000-0001-9419-4624

Specialty section:

This article was submitted to Land, Livelihoods and Food Security, a section of the journal

Frontiers in Sustainable Food Systems

Received: 13 September 2019 Accepted: 03 September 2020

Published: 29 September 2020

Citation:

Medina G, Isley $C$ and Arbuckle $J$ (2020) lowa Farm Environmental Leaders' Perspectives on the U.S. Farm Bill Conservation Programs. Front. Sustain. Food Syst. 4:497943. doi: 10.3389/fsufs.2020.497943
As stakeholders prepare to lobby future Farm Bills, this study reveals farmers' perspectives on federal conservation programs. In-depth interviews were held with ten farm environmental leaders, farmers who have extensive experience with conservation practices and federal conservation programs. Results reveal that conservation programs have played a limited but important role in incentivizing the adoption of and offsetting costs for establishing conservation practices. Programs' strengths, weaknesses, and potential improvements were also explored; results reveal that most farmers believe existing conservation programs could be improved with relatively minor tweaks and adaptations, such as more flexibility in working land program requirements and adjustments to land retirement program payment rates. To some extent, farm environmental leaders also align themselves with the perspectives of environmental NGOs, advocating for transformative approaches, such as expanding mandatory conservation compliance to all cropland, including non-Highly Erodible Lands cropland.

Keywords: conservation stewardship program (CSP), environmental quality incentive program (EQIP), conservation reserve program (CRP), conservation compliance (CC), sustainable farming

\section{INTRODUCTION}

Farmers perceive a tradeoff between short-term profit and long-term environmental sustainability (Arbuckle, 2016; Roesch-McNally et al., 2017). To some extent, U.S. farmers can rely on federal agricultural policy, the Farm Bill, to mitigate the short-term costs of adopting conservation-related practices (Reimer and Prokopy, 2014).

The United States Department of Agriculture (USDA) Farm Bill conservation title includes a number of conservation programs. This research focused on several of the largest and most commonly used: the Conservation Stewardship Program (CSP), the Environmental Quality Incentives Program (EQIP), the Conservation Reserve Program (CRP), and Conservation Compliance (ERS, 2020). The CSP is a working lands program that provides annual and cost-share payments to reward existing conservation practices and promotes further improvements by incentivizing incorporation of new conservation practices over time through 5-year contracts (USDA, 2016). Similarly, EQIP is another working lands program that provides conservation practice cost-share, but with an emphasis on livestock production and through shorter-term contracts for specific practices and conservation planning and technical assistance (USDA, 2018). The CRP is a program that establishes 10 and 15 -year contracts with farmers and landowners to remove environmentally sensitive lands from agricultural production and install resource-conserving practices (Lambert et al., 2007; USDA, 2019). Conservation Compliance is a 
program that ties USDA program benefits such as subsidized crop insurance premiums to environmental performance on sensitive lands such as highly erodible lands (HEL) and wetlands, stipulating that benefits can be lost if, for example, wetlands are converted to crop production or agricultural commodities are produced on HEL without an approved conservation plan or exemption (Arbuckle, 2013). Individual states often have additional conservation programs, but this research has focused on the aforementioned Farm Bill programs.

Farm Bill conservation programs are implemented on a voluntary basis and promote specific practices targeting soil health and water and nutrient management (Lambert et al., 2007; Reimer and Prokopy, 2014). Promoted practices include both structural measures, such as buffer strips, and management measures, such as cover crops (Ulrich-Schad et al., 2017; Stuart et al., 2018).

After decades of investment in conservation-related practices (Mcfadden and Hoppe, 2017), progress can be seen, especially when it comes to the reduction of soil erosion rates (USDA, 2015). But many challenges remain, particularly surrounding soil health and water and nutrient management (Rundquist and Cox, 2016). An understanding of how farmers view conservation programs is fundamental for overcoming these challenges.

Recent studies have provided a comprehensive understanding of the adoption of conservation-related practices by farmers. Adoption is often voluntary, but it can also be catalyzed by conservation programs (Medina et al., 2015; Nebel et al., 2017). Factors explaining adoption range from perceived relative advantage to the cost and risk of trying a new practice (Reimer et al., 2012; Arbuckle and Roesch-McNally, 2015; Prokopy et al., 2019; Ranjan et al., 2019).

Studies have also assessed the reach of Farm Bill conservation programs. They have found great variability in program participation across states (Reimer et al., 2013) and types of farming operations (Lambert et al., 2007). Barriers to participation include farmers' lack of knowledge on existing conservation programs and their requirements (Reimer and Prokopy, 2014; Prokopy et al., 2019; Ranjan et al., 2019).

As stakeholders prepare to lobby future Farm Bills, advocacy groups are proposing changes to Farm Bill programs (Medina et al., 2020). While farmer and commodity groups support adaptions to increase flexibility in conservation programs (Farm Bureau, 2017), environmental NGOs advocate for more transformative and often mandatory approaches (EWG, 2017).

Nonetheless, limited effort has been made to understand farmer perspectives on federal conservation programs. Therefore, this study aims to identify farmer perspectives on Farm Bill conservation programs, including the CSP, EQIP, CRP, and Conservation Compliance programs. Specifically, this study aims to understand farmer perspectives on:

- The role these programs play in supporting adoption of conservation practices;

- These programs' strengths, weaknesses, and potential improvements.

\section{THEORETICAL FRAMEWORK}

We employ a conceptual framework adapted from Hall (1993) and Atwell et al. (2011) to examine farmers' perspectives on the major U.S. federal conservation programs. Policy changes can be divided into three subtypes according to magnitude (Hall, 1993). First and second order changes are likely to display features of incrementalism and development of new policy instruments, but the changed policy is still within the same paradigm (Hall, 1993). Third order change is associated with a change in paradigm, which is preceded by significant shifts in the locus of authority over policy and experimentation with new forms of policy (Hall, 1993).

Policy changes include the fine-tuning of existing policy instruments (tweak), adaptation of the existing instruments (adapt), and overall transformation of the policy (transform) (Atwell et al., 2011). Ranging from incremental tweaks and adaptations to transformative proposals, farmers and stakeholders can be identified along a continuum of paradigmatic orientation (Arbuckle, 2009).

Policy resilience is supported by a capacity to absorb new ideas and still maintain its essential configuration (Atwell et al., 2011). However, the process of internalizing new ideas may result in changes in the locus of authority over policy from one stakeholder to another and a broadening of the policy network (Hall, 1993). Transition theory suggests that, while at times, coherent phases of societal organization can be identified, at other times chaotic transitional characteristics may dominate, leading eventually to a new set of structured coherences (Cloke and Goodwin, 1992).

Interviewed farmers primarily suggest tweaks and adaptations to current conservation programs. These suggested changes are listed by program in our Results section. Several farmers also shared more transformational ideas, which are discussed after the program-by-program results.

\section{MATERIALS AND METHODS}

The study was conducted with farmers in the state of Iowa, which is a major U.S. agricultural producer and has high conservation program payments per capita (Reimer, 2013). Specifically, interviews were held with farmers who had received the Iowa Farm Environmental Leadership (IFEL) Award ${ }^{1}$ for incorporating conservation practices into their farming operations. These farmers had extensive experience implementing conservation practices and participating in Farm Bill conservation programs.

This study analyzed data from in-depth personal interviews with a sample of ten farmers, conducted between October and December 2017. The research focused on farmers who had received the IFEL award in 2012 or 2013, the first 2 years

\footnotetext{
${ }^{1}$ The Iowa Farm Environmental Leader Award is a joint effort of the Governor, Lt. Governor, Iowa Department of Agriculture and Land Stewardship, and Iowa Department of Natural Resources to recognize the exemplary voluntary efforts of Iowa's farmers as environmental leaders committed to healthy soils and improved water quality.
} 
of the program. In 2014, a previous study selected a sample of 20 farmers from the 131 farmers who received the award in the first 2 years of the IFEL (Rosman, 2015). The sample selection process was designed to recruit study participants who were widely recognized as conservation-oriented opinion leaders, even relative to other award winners. Participants were selected based on an Internet search engine query of their names and locations as stated in the public listing of the award recipients. The eligibility criteria for participants was set to be three or more links to media articles featuring their soil and water conservation achievements on the first three pages of search results. Thus, the selected participants were farmers who had been recognized for their stewardship through both the award and multiple instances of recognition in the farm and mainstream media.

Because the 2017 study reported in this paper focuses on farmer perspectives on program participation, we selected a subsample of ten farmers from the 2014 sample whom we knew had substantial experience with conservation programs. Given our research questions and the population of interest (high-level conservation farmers), we feel confident that the sample, both in terms of size and constitution, is appropriate for the scope of the paper. While a sample of ten is on the small side, it can be more than adequate, especially if the research participants are a relatively homogeneous group, as in this case (Guest et al., 2006; Mason, 2010). The sample is biased and not representative of all farmers because it is made up of farmers who are exemplars in terms of their soil and water conservation behaviors and program participation over a long time period. However, we purposely selected them as key informants precisely because they, as exemplars, have unique perspectives that we believe make them ideal participants with whom to engage in semi-structured discussions that evaluate current programs and provide insights into how to shape future conservation policies and programs.

Participants' farm operations had rotations of corn (Zea mays) and soybeans (Glycine max) that are typical of Iowa agriculture, and several farmers also raised some livestock. Farms size varied ranging from 320 acres to 5,000 acres and averaging 1,962 acres (Table 1), compared to the 2017 USDA Census of Agriculture Iowa average of 355 acres (USDA, 2017). Thus, participants were primarily large-scale family farms as defined by the USDA Economic Research Service (Hoppe and MacDonald, 2013). Large-scale family farms participate in conservation programs at a disproportionately high rate compared to small-scale farms (Lambert et al., 2007).

Interviews were held on-site at each farm. Each interview followed the same semi-structured protocol covering the specific objectives outlined in this paper's introduction (see Supplementary Material). After introducing the research objective, we systematically asked all interviewed farmers the same questions. The main topics addressed were: 1. the federal conservation programs interviewed farmers had experience with, 2. their perspectives on those programs based on their own experience (each mentioned program was explored based on its perceived strengths and weaknesses), 3. the actual practices adopted in the farm operation either supported by Farm Bill programs, third-party investments or farmers' out-of-pocket money, and 4. a final question asking their opinion about the
TABLE 1 | Profile of interviewed farmers.

\begin{tabular}{|c|c|c|}
\hline Farmer code & $\begin{array}{l}\text { Farmed area } \\
\text { (in acres) }^{\star}\end{array}$ & $\begin{array}{l}\text { Farm business } \\
\text { enterprises }\end{array}$ \\
\hline 1 & 2,000 & $60 \%$ corn, $40 \%$ soybeans \\
\hline 2 & 3,600 & $\begin{array}{l}60 \% \text { corn, } 40 \% \text { soybeans, } 4,800 \text { head } \\
\text { hog finishing }\end{array}$ \\
\hline 3 & 1,000 & $50 \%$ corn, $50 \%$ soybeans \\
\hline 4 & 800 & $50 \%$ corn, $50 \%$ soybeans \\
\hline 5 & 1,200 & $\begin{array}{l}3 \text { years corn } 11 \text { year soybean rotation, } \\
\text { farrow-to-finish operation }\end{array}$ \\
\hline 6 & 1,000 & 2-year corn/soybean rotation \\
\hline 7 & 1,500 & $50 \%$ corn, $50 \%$ soybeans \\
\hline 8 & 5,000 & $\begin{array}{l}\text { Variable rotations of corn and soybeans, } \\
\text { runs a precision agriculture equipment } \\
\text { dealership }\end{array}$ \\
\hline 9 & 3,200 & Variable rotations of corn and soybeans \\
\hline 10 & 320 & $\begin{array}{l}\text { Half row-crop, half non-tillable (pasture, } \\
\text { CRP), } 40 \text { head of cattle }\end{array}$ \\
\hline
\end{tabular}

*Includes both owned and rented land.

potential expansion of conservation compliance to all cropland, including non-Highly Erodible Land (HEL) cropland.

Each of these main questions were followed by clarification questions, and on average, interviews lasted for $1.5 \mathrm{~h}$. In some cases, when suggested by farmers, interviews were followed by a visit to farm fields, barns, etc.

All interviews were recorded and transcribed. We analyzed the interview data employing a hierarchical coding procedure to identify themes under each set of questions (Corbin and Strauss, 1990). Preliminary analysis of the interview data consisted of code development based on the interview protocol questions, and coding of transcribed responses to questions about the programs (e.g., CSP strength, EQIP weakness). Transcripts were further coded using the "tweak, adapt, transform" framework to identify emergent themes associated with farmers' assessments of how programs and policies might be improved. The first author was the primary coder and the third author reviewed the coded transcripts to enhance reliability. Finally, we include direct quotes to improve the validity and transparency of the analysis and provide readers with nuanced details of context and meanings within the interview data (Prokopy, 2011). Results are presented in comparative tables, and predominant outcomes are illustrated by quotes. Each farmer has authorized this information to be shared, provided that his or her identity would not be revealed.

\section{RESULTS}

\section{Federal Conservation Programs' Role in the Adoption of Conservation Practices}

Federal conservation programs have covered costs associated with some practices adopted by study participants, though other practices have been paid for with out-of-pocket or third-party investments (Figure 1). Overall, CSP had provided farmers an incentive to enhance their conservation practices, 


\begin{tabular}{|c|c|c|c|c|c|c|c|c|}
\hline Farm & CSP promoted practices & Year & Status & & Farm & Out-of-pocket investment & Year & Status \\
\hline \multirow[t]{2}{*}{1} & \multirow{2}{*}{$\begin{array}{l}\text { No-till ahead of soybeans and strip-till } \\
\text { ahead of corn }\end{array}$} & \multirow[t]{2}{*}{1993} & \multirow[t]{2}{*}{ Integrated } & & \multirow[t]{3}{*}{1} & Nutrient management & 2008 & Integrated \\
\hline & & & & & & Set asidehilltops & $\cdot$ & Integrated \\
\hline \multirow[t]{2}{*}{2} & \multirow{2}{*}{$\begin{array}{l}\text { Conservation tillage, terraces and } \\
\text { nutrient management }\end{array}$} & \multirow[t]{2}{*}{2000} & \multirow[t]{2}{*}{ Expansion } & & & Buffer along stream & - & No longer \\
\hline & & & & & \multirow[t]{3}{*}{2} & Nutrient management (soil sampling, & 2006 & Integrated \\
\hline \multirow[t]{3}{*}{3} & \multirow{2}{*}{$\begin{array}{l}\text { No-till, buffer strip along creek and set- } \\
\text { aside land with wildflowers (nolonger) }\end{array}$} & \multirow[t]{2}{*}{1980} & \multirow[t]{2}{*}{ Integrated } & & & manurespreading) & & \\
\hline & & & & & & No-till (40 acres) & 2017 & Trial \\
\hline & Nutrient management & 1997 & Adjusting & & 3 & Terraces & 1994 & Adjusting \\
\hline \multirow[t]{2}{*}{6} & Strip-till ( $100 \%$ of farm) & 2008 & Integrated & & \multirow[t]{3}{*}{4} & \multirow{2}{*}{$\begin{array}{l}\text { No-till for soybeans, strip-till for com } \\
\text { and nutrient management }\end{array}$} & \multirow[t]{2}{*}{1996} & \multirow[t]{2}{*}{ Integrated } \\
\hline & Nutrient management & 1980 & Integrated & & & & & \\
\hline \multirow[t]{2}{*}{7} & No-till (on about $20 \%$ of acres) & $\cdot$ & Expansion & & & Cover crops and waterways & 2015 & Trial \\
\hline & Integrated pest and nutrient management & - & Integrated & & \multirow[t]{3}{*}{5} & Conservation tillage and nutrient & 2001 & Integrated \\
\hline 9 & Terraces & 1990 & Integrated & & & management (spring-applied nitrogen) & & \\
\hline \multirow[t]{2}{*}{10} & \multirow{2}{*}{$\begin{array}{l}\text { Rotational grazing and nutrient } \\
\text { management }\end{array}$} & \multirow[t]{2}{*}{-} & \multirow[t]{2}{*}{ Integrated } & & & Cover crops and strip till & 2015 & No longer \\
\hline & & & & & 7 & Waterways & 1982 & Integrated \\
\hline Farm & EQIP promoted practices & Year & Status & & 8 & Nutrient management and waterways & 2008 & Integrated \\
\hline 1 & Cover crops (used on $80 \%$ of the farm) & 2014 & Expansion & & & Precision agriculture with grid soil & - & Integrated \\
\hline 2 & Cover crops (used for threeyears) & 2014 & No longer & & & sampling and conservation tillage & 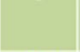 & Mестане \\
\hline 3 & Cover crops & 2015 & Trial & & 9 & Prairiestrip & 1990 & Integrated \\
\hline 6 & $\begin{array}{l}\text { Windbreaks } \\
\text { Side-dresser purchase }\end{array}$ & 1999 & $\begin{array}{l}\text { Integrated } \\
\text { Integrated }\end{array}$ & & 10 & Extended crop rotation (com, & - & Integrated \\
\hline 8 & Strip-till (on $1 / 3$ of the farm) & 2008 & Integrated & & & soybeans, oats, alfalfa) & & \\
\hline & Cover crops on tworented farms & 2008 & Trial & & Farm & Other sources & Year & Status \\
\hline 9 & Nutrient management & $\cdot$ & Integrated & & 2 & Bioreactor - $100 \%$ paid through non- & 2008 & Trial \\
\hline 10 & Cover crops (100 acres) & 2014 & Expansion & & & federal organization & & \\
\hline & Pond and waterways & $\cdot$ & Integrated & & 4 & Pollinator habitat (one acre) - cost- & $\cdot$ & Integrated \\
\hline Farm & CRP promoted practices & Year & Status & & & sharefrom pheasants forever/DNR & & \\
\hline 1 & Waterways and set aside three hilltops & - & Integrated & & 7 & Cover crops - cost-share from ADM's & $\cdot$ & Integrated \\
\hline 2 & Waterways ( $1 / 4$ is CRP) & 2000 & Integrated & & & sustainability program & & \\
\hline & Filter strip along an open ditch & 2009 & No longer & & 8 & Bioreactor - $100 \%$ paid through non- & 2008 & Trial \\
\hline 3 & Waterways and wetlands & $\cdot$ & Integrated & & & federalorganization & & \\
\hline 4 & Buffer strips along streams ( 60 acres) & 1999 & Integrated & & 9 & $\begin{array}{l}\text { Cover crops and bioreactor - } 100 \% \\
\text { paid throughnon-federal organization }\end{array}$ & 2008 & Trial \\
\hline 5 & Wetlands & - & Integrated & & & paid throughnon-federal organization & & \\
\hline 6 & Buffer strips and pollinator habitat & 2009 & Integrated & & Farm & Conservation Compliance & Year & Status \\
\hline & Ponds & 1962 & Integrated & & 1 & No-till & - & Integrated \\
\hline 7 & Buffer strips & $\cdot$ & Integrated & & 2 & Conservationtillage & - & Integrated \\
\hline 8 & Buffer strips & 2008 & Integrated & & 3 & No-till, terraces & - & Integrated \\
\hline 9 & Buffer strips and stream restoration & 1990 & Integrated & & & & & \\
\hline 10 & Buffer strips and set aside hillsides & - & Integrated & & & & & \\
\hline
\end{tabular}

FIGURE 1 | Conservation-related practices adoption process by farm environmental leaders in lowa. Source: Field research. Interviewed farmers define reduced tillage practices as follows: conservation tillage-tillage with some residue left covering soil; strip-tillage-disturbs only the portion of the soil that is to contain the seed row; no-till-no soil disturbance. Conventional tillage is defined as tillage with no residue left covering soil. In the case of conservation compliance, only farmers with HEL were reported.

often through the implementation of conservation tillage and nutrient management plans. EQIP had also aided in conservation adoption, often incentivizing farmers to try cover crops. Many of the practices that improve wildlife habitat and water quality, such as pollinator habitat and buffer strips, were established with support from CRP. Conservation Compliance had had less of an impact among the interviewed farmers, but it had helped catalyze the adoption of conservation tillage in a few cases.

For interviewed farm environmental leaders, federal conservation programs had played an important role in incentivizing conservation efforts. Many interviewed farmers cited these programs as a reason they adopted the practices they have: "I bought my side-dresser 18 years ago because the EQIP program, state EQIP, they paid for it.... the payment each year was like four thousand dollars....And I took them dollars and paid [for the side-dresser] and we still have the side-dresser, we're still using it" (Farmer 6). Farmer 8 shared a similar sentiment: "The government money has been a big help. Because when profit margins are low, are we able to show a return on the year we do it (implement conservation practices)? Not necessarily" (Farmer 8).

Some practices, such as no-till and strip-till, had been a part of participants' farming operations for a relatively long time (Figure 1). Other conservation practices, particularly cover 
crops, were newer and in the process of being adopted by farmers. Many farmers discussed how high implementation costs had been a barrier to cover crop use: "I've tried cover crops out here. ... I've got all this other work to do and then for me to go and spend fifty dollars an acre to put a cover crop out there that's going to possibly save thirty pounds of nitrogen? The economics isn't there for that" (Farmer 5). "It can work. But you know, it's, there again, a pretty expensive thing to do. Until you see the benefit of increased soil activity and what not, it's hard to get a return off of that or see a return" (Farmer 4).

Several farmers directly emphasized the importance of government programs in overcoming this cost barrier: "It's expensive, and once again the government will pay you for one time to use cover crops. Well, the way to put it on is with an airplane. That gets pretty expensive. Again, how do you pay for this without government subsidy?" (Farmer 6). "I've had costshare for cover crops. ... We really can't afford to do a cover crop without cost-share. And even with cost share, it doesn't come close to covering the cost" (Farmer 9). "Recently there's the cover crop push, so Badger Creek Watershed was slated for extra [EQIP] funding. So I decided it was a good opportunity to get on board with that" (Farmer 10). These quotes illustrate how participants valued government conservation programs to incentivize adoption of new practices, especially cover crops.

Several interviewed farmers, however, had also implemented multiple practices using their own money with no government support. Figure 1 differentiates practices adopted due to Farm Bill conservation programs incentives (on the left side) from practices adopted through out-of-pocket investments and thirdparty investments (on the right side). Many participants expressed that they feel a responsibility to be a good steward regardless of the availability of public funds: "I had looked at that [the CSP program], I was real enthused about that, and just never did get into it. I guess I thought it's kind of a philosophy, what's right I should do on my own. I shouldn't take government money for doing something that's right" (Farmer 4).

Other participant farmers cited inflexible requirements as reasons for not using Farm Bill conservation programs: "We were limited on what we could put for nitrogen. When corn and bean prices went up, we kind of got up on our nitrogen rate, shooting for higher yields. ... So that's kind of why I got out of that program. It just wasn't working. ... I felt like it [the CSP program] could be holding us back on our yield potential and profitability a little bit" (Farmer 2). Farmer 5 shared a similar sentiment regarding conservation program requirements: "I went up to my NRCS [office] ... and I said I put Agrotain on late-season application nitrogen, do I qualify for this $\$ 25$ an acre? ... They said, well, Agrotain isn't approved. The only thing that is approved is N-Serve.... Agrotain does the same thing for liquid nitrogen, but they didn't recognize it, so I didn't quality for it [the EQIP program]. Frustration!” (Farmer 5).

\section{Programs' Strengths, Weaknesses, and Potential Improvements}

Interviewed farmers provided insight into the perceived strengths and weaknesses of conservation programs, and many farmers also discussed recommendations on how programs' shortcomings can be addressed. In nearly all cases, farmers described each program's positives in very general terms (saying they have had generally good experiences with certain programs, overall they like certain programs, etc.) while they described the negatives more specifically. Therefore, this section primarily focuses on programs' weaknesses and how study participants believed each program could be improved. Some farmers were poorly aware of administrative details of individual programs, but all were able to identify which programs they have used and were able to give insight into their experiences. Many of their resulting recommendations involved specific tweaks and adaptations to existing programs, but other recommendations involved the transformation of current approaches and mentalities.

\section{CSP}

Though many farmers reported that their overall impression of CSP was positive, all interviewed farmers who had experience with the program had at least one critique (Table 2). The biggest complaints surrounded the program's inflexible requirements and decreased payment rates.

One farmer recalled a particular experience with CSP's rigid requirements:

"I remember going into NRCS... and I complained. I said I want to be a part of this program [CSP] but it's real difficult to get enough points to get above Tier 1 because it's so heavily no-till oriented. And the comment I got from the NRCS guy was, "Well, everybody should no-till." That's very frustrating to me... It's a lot different how I farm here than in southern Iowa. And that's a frustration I have with government programs because they always want to treat us as farming the same way." (Farmer 5)

Another interviewed farmer shared the same sentiment:

\begin{abstract}
"The government requires you to do things almost to the letter. ... I don't really care for tissue samples-they have more sophisticated tools now to measure nitrogen in the soil. Well, no, we've got to have tissue samples [to meet CSP requirements].... If you agree to do this practice, you pretty much have to do it the way they state. And that's why a lot of farmers don't like the CSP. It's too confining." (Farmer 7)
\end{abstract}

Overall, four of the ten interviewed farmers cited inflexible requirements as a weakness of the CSP program (Table 2).

The same number of farmers commented on CSP's reduced payments: "They aren't paying as much now as they did... they cut it [the CSP payment rate] down quite a bit. I think the max is around \$28 an acre now. Which is still fine, but it [higher payments] just helps offset some of those costs" (Farmer 7). "It (the CSP program) has been a help, an incentive. In years like this I'm glad the check is in the mail.... I remember at the signup thinking, "Is this worth it?." As I recall, the funding dropped from my initial contract to the second contract. The amount of funding went down, and the enhancements became a little more challenging" (Farmer 10).

Farmer 10 also brings up another theme: that CSP "enhancements" (conservation steps taken to maintain or 
TABLE 2 | Farm environmental leaders' perspectives on conservation programs.

\begin{tabular}{|c|c|c|c|c|}
\hline Program & Farmer & Program status & Improvement & Perspectives \\
\hline \multirow[t]{5}{*}{ CSP } & 1 & Enrolled & Budget & $\begin{array}{l}\text { Promising program, but congress decreased its budget, so farmers didn't get } \\
\text { the benefit they should have }\end{array}$ \\
\hline & 3 & No longer enrolled & Requirements & $\begin{array}{l}\text { We had a positive experience, but to stay in the program you have to do more. } \\
\text { Some of the additional enhancements made no sense }\end{array}$ \\
\hline & 6 & No longer enrolled & Payments & $\begin{array}{l}\text { CSP should continually pay farmers for conservation practices, not just } \\
\text { incentivize farmers to get started on a practice }\end{array}$ \\
\hline & 7 & Enrolled & Requirements, payments & $\begin{array}{l}\text { Overall, it has been a good experience. Requirements can be restrictive, though. } \\
\text { You have to do every practice just the way they say }\end{array}$ \\
\hline & 10 & Enrolled & Requirements & $\begin{array}{l}\text { Positive experience overall. Provides a good incentive to help further improve } \\
\text { conservation. Payments are helpful, though they aren't as high as they used to } \\
\text { be. The program doesn't allow for spontaneity }\end{array}$ \\
\hline
\end{tabular}

\begin{tabular}{|c|c|c|c|c|}
\hline \multirow[t]{6}{*}{ EQIP } & 1 & Enrolled & Paperwork, requirements & $\begin{array}{l}\text { Cover crop cost-share was a frustrating experience because of excessive } \\
\text { paperwork, strict seed mix requirements, and slow payments }\end{array}$ \\
\hline & 3 & Never enrolled & Budget & Have tried to sign up twice, but it was full both times. Budget isn't big enough \\
\hline & 5 & Never enrolled & Requirements, county differences & $\begin{array}{l}\text { Some requirements are needlessly strict. I used a nitrogen stabilizer but didn't } \\
\text { qualify for the program because it wasn't their approved brand. Also, EQIP is run } \\
\text { by the county, which results in unfair county-by-county differences }\end{array}$ \\
\hline & 6 & No longer enrolled & Requirements & $\begin{array}{l}\text { In some cases, the government pays for things that don't need to be done. For } \\
\text { example, cover crops work on some acres, but in other cases they aren't the } \\
\text { best option }\end{array}$ \\
\hline & 7 & No longer enrolled & Payments & $\begin{array}{l}\text { The program's budget and cost-share rates are weaknesses. You get paid well } \\
\text { the first year, but payments are lower after that. It's hard to get re-enrolled at all }\end{array}$ \\
\hline & 9 & No longer enrolled & Payments & $\begin{array}{l}\text { The program doesn't pay enough. I use ADM's cost-share program now, and it } \\
\text { pays significantly more }\end{array}$ \\
\hline \multirow[t]{6}{*}{ CRP } & 1 & Enrolled & Requirements, payments & $\begin{array}{l}\text { Some requirements are nitpicky and illogical. Also, CRP payments didn't keep } \\
\text { up with the rising rental rates }\end{array}$ \\
\hline & 3 & Enrolled & Requirements & $\begin{array}{l}\text { Some requirements are non-sensical and prevent good outcomes. For example, } \\
\text { we had a wetland in CRP for } 15 \text { years, but we have to farm it for } 3 \text { years before } \\
\text { we can enroll it again }\end{array}$ \\
\hline & 4 & Enrolled & Payments, requirements & $\begin{array}{l}\text { Good program. Payments were previously too low, but now they're too high. } \\
\text { They lag behind rental rates and should be adjusted on an annual basis. Mid } \\
\text { contract management requirements could be made more flexible, too }\end{array}$ \\
\hline & 5 & Enrolled & Payments & $\begin{array}{l}\text { The program is good in theory, but its implementation can be frustrating. Rates } \\
\text { should be based on current economics and determined yearly }\end{array}$ \\
\hline & 6 & Enrolled & Targeting & $\begin{array}{l}\text { People shouldn't be able to enroll entire fields of flat land. Eligibility should be } \\
\text { based on slope and proximity to bodies of water }\end{array}$ \\
\hline & 8 & Enrolled & Payments & $\begin{array}{l}\text { CRP payments are high compared to cash rents, so CRP competes with } \\
\text { renters. CRP payments should be more in line with cash rents }\end{array}$ \\
\hline
\end{tabular}

Source: Field research. Farmers who had no comments or had never tried to enroll with specific programs are not listed. 
improve CSP status) do not meet some farmers' needs and goals, especially as they move further along in the program. For example, farmer 3 stated: "In order now to stay in it [CSP] you have to do more. We were already at the top. Some of the things that you had to do [to progress in the program] really didn't make sense. So we're not in that anymore." Interviewed farmers also felt that enhancements may not be a good fit for operations that include rented land (Table 2).

\section{EQIP}

As with CSP, payment rates and strict requirements were the most frequently reported weaknesses of EQIP. One interviewed farmer cited payment rates as a reason he had switched to private cost-share programs:

\begin{abstract}
"Yeah, I use cost-share on that [cover crops]. It was NRCS, and then I'm with ADM.... The first year you do it (EQIP), they'll cost share $\$ 25$ an acre. And then after you've done that it goes down to $\$ 15$ an acre, and you have to get in there pretty quickly or else the money is gone. The sustainability program I'm with at ADM, they'll pay $\$ 25$ an acre, plus I still get the ten cents for the beans too [ten cents per bushel sustainability premium]." (Farmer 7)
\end{abstract}

Another farmer, also involved with Archer Daniels Midland's sustainability program, shared similar thoughts: "If I went through state [EQIP]-I've raised cover crops before-I'd get a fifteen dollar an acre subsidy. If I go through ADM, I still get the twenty-five dollars" (Farmer 9).

Other farmers critiqued the program's red tape and strict requirements:

\begin{abstract}
"Very, very frustrating. I signed all the papers, thought we had signed all the papers. I think we went back either three or four times to sign papers.... Even that [the seed mix requirement] was somewhat frustrating in that you've got to go up and get approval for a given mix with a given amount per acre. And we thought we had everything all set up, and oh no, you can't do that. You've got to have either a different species in there or you've got to have more per acre. Well what's the difference if you get a good cover crop?" (Farmer 1)
\end{abstract}

Two other interviewed farmers shared similar opinions, as evidenced in Table 2.

County-by-county differences in EQIP implementation was another weakness cited by one farmer: "The EQIP program is run by the county. ... our NRCS guy only wants to do large projects.... He wants to spend the money on one or two farmers in the county. Other counties do a better job of that [spreading money around]. So there's another frustration, how it's managed. It's different from one county to another" (Farmer 5).

\section{CRP}

Many interviewed farmers viewed CRP as a good program in the sense that it results in positive environmental benefits; however, eight of the ten farmers believed the program had at least one weakness (Table 2). The CRP payment rate was the most frequently discussed weakness, mentioned by four farmers.
Specifically, farmers expressed that the rate is not aligned wellenough with cash rents: "Right now cash rent is running $\$ 240$ to $\$ 260$ in this area, and CRP is paying like $\$ 320$ or $\$ 350 \ldots$ the CRP will compete with us [renters] for acres" (Farmer 8). Multiple farmers suggested more frequent rate adjustments to solve this problem: "I think you can have a 10-year contract, but maybe how much you get should be based as a year-to-year thing" (Farmer $4)$; "To me it should be a yearly rate based on the economics" (Farmer 5).

Several farmers also cited certain program requirements as weaknesses, suggesting that some rules may actually be preventing environmentally beneficial outcomes: "We had a square patch that was in the early CRP.... It came out this year, and he had to put it back in, and he had to kill the seeding on the hill-spray it and kill it-and re-seed it to the weed mix, the pollinator mix. [It was] wonderfully established, couldn't have been better as far as stabilizing the soil and all that kind of stuff" (Farmer 1). Another farmer had a similar experience with a wetland enrolled in CRP:

"You put it in for 15 years, but you take your payments over 10 years. And then they said even though you didn't get a check for that 5 years, you have to treat it like it wasn't farmed. And so you have to start all over again if you wanted to put it back into a CRP program, because it has to have been farmed 3 of the 5 years previous.... (in order to get it into a different program) we actually had to start farming it." (Farmer 3)

Other interviewed farmers suggested CRP could be improved by being better targeted to environmentally sensitive land: "I think from an environmental standpoint, we should be targeting CRP. We shouldn't be putting really good land into CRP, I don't think. We should be paying more to get the poor land in. Right now you get paid more if you put good land in" (Farmer 9). "There's now quarter sections of good, black, flat ground that should be in production that are getting $\$ 300$ an acre in CRP. ... Why did they allow that?... It (the CRP rate) is based off of the corn suitability rating... it should be based off of slope factors and closeness to open water" (Farmer 6).

\section{Transformations}

Most participants suggested improvements that involved relatively small changes to existing conservation programs, as illustrated above. These changes fall under the categories of "tweak" or "adapt." However, most interviewed farmers also proposed more transformational changes that did not necessarily fall under the umbrella of individual conservation programs.

Several farmers expressed that landlords' mentalities toward conservation must change, especially when it comes to their unwillingness to compensate farmers for adopted practices: "They want the same cash rent [for land with conservation].... I [the landlord] want X dollars an acre. You (the farmer) take care of everything. If you want, put it in CRP. Whatever you want, that's just fine with me as long as I get my cash rent" (Farmer 1). "We have something like twenty-five landlords, and it's a lot more difficult to put conservation practices on rented land because we can't afford to pay for it. ... The land I own has a lot more conservation on it than land I don't own" (Farmer 9). 
And some study participants, although opposed to government interference, doubted the effectiveness of the current voluntary programs and acknowledge that mandatory approaches may be on the horizon: "People (farmers) don't care (about conservation). And I think what's going to bring it around, and I don't want mandates, is when the people in the city and the country don't have fresh water. Look at the lawsuit from Des Moines... When it gets mandated then we're going to have to wake up" (Farmer 6).

Along the lines of mandated conservation, farmers were asked their opinion on the expansion of conservation compliance, which currently applies only to farmland classified as highly erodible land (HEL), to all cropland. Surprisingly-given the complaints about red tape and strict requirements for CSP, EQIP, and $\mathrm{CRP}$ - eight of the ten farmers expressed what we believe to be a transformative view, in that they would support the program's expansion beyond HEL (Table 3). Several farmers cited the need for accountability as rationale for this viewpoint. Farmer 8 explained, "If the government's kicking in money (for subsidized crop insurance), it's not wrong to ask them (those who receive it) to be accountable. ... For Iowa I think it's [expanding conservation compliance] well-justified" (Farmer 8). Farmer 7 shared a similar opinion: "I don't think it [expanding conservation compliance] would be a bad thing. I think the taxpayers are asked to spend a lot of money on this cost-share. ... If you're going to take the taxpayers' money to buy down your crop insurance, you should give something back in return" (Farmer 7).

Other farmers believed expanding conservation compliance would help improve tillage practices: "It just blows my mind. You can take one little piece of ground and call it HEL and you've got to follow all these certain restrictions, but yet the neighbor across the road, they're tilling it until it's black. ... If they come out with something like that [expanded conservation compliance], I wouldn't be opposed to it because we've got to cut back on tillage I think" (Farmer 2). "I think it [expanding conservation compliance] would be a terrific idea.... [It would] maybe be an incentive for farmers that are plowing up right now... They don't need to do that. So give them an incentive to wait until spring to do whatever field work they are going to do" (Farmer 3).

\section{CONCLUSION}

Results revealed that many of the farm environmental leaders we interviewed had had generally positive experiences with federal conservation programs, but many were also quick to point out programs' weaknesses and suggest potential improvements. Conservation programs had covered part of the costs for establishing practices, but nine of the ten interviewed farmers had implemented at least one practice with out-of-pocket or third-party investments. Some believed that conservation is their own responsibility as a good steward, and therefore were not as involved in conservation programs. Others cited red tape, external interference in their farming operations, or low payment rates as reasons for not utilizing federal dollars. Nonetheless, for most participants conservation programs had
TABLE 3 | Farm environmental leaders' perspectives on the expansion of conservation compliance (favorable views in light green).

\begin{tabular}{|c|c|c|}
\hline Farmer & Status & Perspective \\
\hline 1 & HEL & $\begin{array}{l}\text { We have some land that's HEL. It's long-term no-till at this } \\
\text { point, which keeps the NRCS happy. Expanding conservation } \\
\text { compliance would be a good thing, but I don't think it'll } \\
\text { happen }\end{array}$ \\
\hline 2 & HEL & $\begin{array}{l}\text { We have some HEL ground. We're just required to leave a } \\
\text { certain amount of residue on it. If conservation compliance } \\
\text { was expanded, I wouldn't be opposed to it; we need to } \\
\text { reduce tillage }\end{array}$ \\
\hline 3 & HEL & $\begin{array}{l}\text { We have one farm that's HEL. We have terraces on it and do } \\
\text { no-till. I think expanding conservation compliance would be a } \\
\text { terrific idea. Many farmers plow up everything, including } \\
\text { soybean ground. Maybe this would incentivize them to } \\
\text { reduce their tillage }\end{array}$ \\
\hline 4 & No HEL & $\begin{array}{l}\text { I am definitely in favor of crop insurance and conservation } \\
\text { compliance being coupled together on HEL. I'm not opposed } \\
\text { to this being expanded to non-HEL, but I also don't like being } \\
\text { told how to run my farm }\end{array}$ \\
\hline 5 & No HEL & $\begin{array}{l}\text { I strongly oppose expanding conservation compliance. } \\
\text { Regulations don't work. They don't level the playing field. I } \\
\text { can do a better job managing my farm than someone sitting } \\
\text { in Washington D.C. The program has implementation issues, } \\
\text { too; people who have done the right thing have been found } \\
\text { out of compliance simply due to weather events }\end{array}$ \\
\hline 6 & No HEL & $\begin{array}{l}\text { Expanding conservation compliance would force farmers to } \\
\text { do conservation practices to get their subsidies. Wouldn't you } \\
\text { as a taxpayer want to see a benefit from the subsidies you } \\
\text { pay for? }\end{array}$ \\
\hline 7 & No HEL & $\begin{array}{l}\text { I don't think expanding conservation compliance would be a } \\
\text { bad thing. Taxpayers spend a lot of money on crop insurance } \\
\text { cost-share. In order to get subsidized you should give } \\
\text { something back }\end{array}$ \\
\hline 8 & No HEL & $\begin{array}{l}\text { If the government is kicking in money by subsidizing your } \\
\text { crop insurance, it's not wrong to ask you to be accountable. } \\
\text { Expanding conservation compliance would be fine in lowa, } \\
\text { but I can't speak for other states }\end{array}$ \\
\hline 9 & No HEL & $\begin{array}{l}\text { I've been a big promoter of expanding conservation } \\
\text { compliance, and I think every farm should have a } \\
\text { conservation plan }\end{array}$ \\
\hline 10 & - & - \\
\hline
\end{tabular}

Source: Field research.

played an important role in incentivizing adoption and offsetting costs of conservation practices. Building on previous studies (Reimer et al., 2012; Arbuckle and Roesch-McNally, 2015; Nebel et al., 2017), these findings emphasize the relevance of conservation policies in helping reduce risk for farmers trying new practices.

According to interviewed farmers, all three of the federal conservation programs discussed could benefit from more flexible requirements and higher payment rates. Programspecific tweaks and adaptions were also suggested: CSP could be improved with some adjustments to enhancements, EQIP with more uniform implementation, and CRP with more targeted implementation. Changes such as these could potentially increase farmers' participation in federal conservation programs and catalyze conservation nationwide. 
While many of participants' suggestions involved tweaks and adaptions to existing programs, others pointed toward major policy transformations (Hall, 1993; Atwell et al., 2011). A full $80 \%$ of the interviewed Iowa farm environmental leaders favored more transformative actions such as expanding conservation compliance to all cropland, providing incentives to landowners to help overcome the challenges faced by renters, and even regulatory measures. In contrast to participant farmers, more traditional and powerful organizations, such as the Farm Bureau, tend to support adaptations but not transformative approaches to existing Farm Bill conservation programs (Medina et al., 2020).

Interviewed farmers discussed the challenges of implementing conservation on rented acres, the possibility of mandatory conservation regulations, and showed support for the expansion of conservation compliance to all cropland. Challenges such as how to promote conservation practices to a growing number of tenant farmers and landlords have also been reported elsewhere (Varble et al., 2016). As these issues are not addressed by current programs, they may require a more transformative approach in future policy revisions.

As stakeholders prepare to lobby future Farm Bills, it is critical to consider farmers' perspectives on federal conservation programs (Roesch-McNally et al., 2017). To some extent, the farm environmental leaders interviewed aligned themselves with the perspectives of environmental NGOs, advocating for transformative approaches, such as the extension of Conservation Compliance to all farms receiving crop insurance subsidies. But in many issues interviewed farmers also share views with commodity and farmer groups, preferring less red tape and more flexibility within federal conservation programs (Medina et al., 2020).

This study focused only on farmers who had been formally recognized as environmental leaders. Thus, they were exemplars of farmers who have strong conservation ethics and operationalize them through the establishment much greater levels of soil and water conservation practices than is typical. In this sense, the results presented here do not represent perspectives of farmers in general across U.S. agricultural systems. Future research efforts should focus on less conservation-oriented farmers to evaluate their perspectives on the strengths and weaknesses of conservation programs. That said, these exemplary farmers who had substantial knowledge of and experience with major U.S. soil and water conservation programs provided important insights into the strengths and weaknesses of programs and how they fit or did

\section{REFERENCES}

Arbuckle, J. (2013). Farmer support for extending conservation compliance beyond soil erosion: evidence from Iowa. J. Soil Water Conserv. 68, 99-109. doi: $10.2489 /$ jswc.68.2.99

Arbuckle, J. (2016). Iowa Farm and Rural Life Poll: 2015 Summary Report. Extension report PM 3016, Iowa State University. not fit within their long-term economic and environmental sustainability strategies. Their perspectives helped point to potential improvements that could be made to current programs, suggested alternative conservation programs/measures, and importantly, potential transformations in conservation policy (e.g., extension of conservation compliance to all cropland) that could lead to major increases in soil and water conservation actions across the U.S. agricultural landscape.

\section{DATA AVAILABILITY STATEMENT}

The datasets generated for this study will not be made publicly available in order to protect farmers' identity.

\section{ETHICS STATEMENT}

The studies involving human participants were reviewed and approved by Iowa State University. Written informed consent for participation was not required for this study in accordance with the national legislation and the institutional requirements.

\section{AUTHOR CONTRIBUTIONS}

GM and JA: carried out fieldwork in Iowa. CI supported data processing. All authors listed have made a substantial, direct and intellectual contribution to the written work, and approved it for publication.

\section{FUNDING}

This research was also supported in part by the Iowa Agriculture and Home Economics Experiment Station, Ames, Iowa.

\section{ACKNOWLEDGMENTS}

The authors wish to thank the Fulbright Scholar Program for their support for the first author's visit to Iowa State University. We also wish to thank Hanna Bates, whose MS thesis research (Rosman, 2015) laid the groundwork for this research project.

\section{SUPPLEMENTARY MATERIAL}

The Supplementary Material for this article can be found online at: https://www.frontiersin.org/articles/10.3389/fsufs. 2020.497943/full\#supplementary-material 
Atwell, R. C., Schulte, L. A., and Westphal, L. M. (2011). Tweak, adapt, or transform: policy scenarios in response to emerging bioenergy markets in the U.S. corn belt. Ecol. Soc. 16:10. doi: 10.5751/ES-03854-160110

Cloke, P. J., and Goodwin, M. (1992). Conceptualising countryside change: from post-fordism to rural structured coherence. Trans. Instit. Br. Geogr. NS17, 321-336. doi: 10.2307/622883

Corbin, J., and Strauss, A. (1990). Grounded theory research: procedures, canons, and evaluative criteria. Qual. Sociol. 13, 3-21. doi: 10.1007/BF00988593

ERS (2020). USDA ERS-Conservation Programs. Available online at: https://www. ers.usda.gov/topics/natural-resources-environment/conservation-programs/ (accessed August 21, 2020).

EWG (2017). Less Farm Pollution, More Clean Water: An Agenda for Conservation in the 2018 Farm Bill. Ames, IA: EWG. p. 7.

Farm Bureau (2017). 2017 Policy Book. Jefferson City, MO; Missouri Farm Bureau. p. 136.

Guest, G., Bunce, A., and Johnson, L. (2006). How many interviews are enough? Field Methods 18, 59-82. doi: 10.1177/1525822X05279903

Hall, P. (1993). Policy paradigms, social learning, and the state: the case of economic policymaking in Britain. Comp. Polit. 25, 275-296. doi: $10.2307 / 422246$

Hoppe, R. A., and MacDonald, J. M. (2013). Updating the ERS farm typology. SSRN Electron. J. 110. doi: 10.2139/ssrn.2267293

Lambert, D. M., Sullivan, P., Claassen, R., and Foreman, L. (2007). Profiles of US farm households adopting conservation-compatible practices. Land Use Policy 24, 72-88. doi: 10.1016/j.landusepol.2005.12.002

Mason, M. (2010). Sample size and saturation in $\mathrm{PhD}$ studies using qualitative interviews. Forum Qual. Soc. Res. 11, 1-19. doi: 10.17169/fqs-11.3.1428

Mcfadden, J. R., and Hoppe, R. A. (2017). The Evolving Distribution of Payments From Commodity, Conservation, and Federal Crop Insurance Programs. Washington, DC: USDA.

Medina, G., Isley, C., and Arbuckle, J. (2020). Promoting sustainable agriculture: Iowa stakeholders' perspectives on the US Farm Bill conservation programs. Environ. Dev. Sustainability. doi: 10.1007/s10668-019-00572-5

Medina, G., Potter, C., and Pokorny, B. (2015). Farm business pathways under agrienvironmental policies: lessons for policy design. Estud. Soc. Agric. 23, 5-30. Available online at: https://revistaesa.com/ojs/index.php/esa/article/view/493

Nebel, S., Brick, J., Lantiz, V., and Trenholm, R. (2017). Which factors contribute to environmental behaviour of landowners in Southwestern Ontario, Canada? Environ. Manage. 60, 454-463. doi: 10.1007/s00267-017-0849-9

Prokopy, L. S. (2011). Agricultural human dimensions research: the role of qualitative research methods. J. Soil Water Conserv. 66, 9A-12A. doi: 10.2489 /jswc.66.1.9A

Prokopy, L. S., Floress, K., Arbuckle, J. G., Church, S. P., Eanes, F. R., Gao, Y., et al. (2019). Adoption of agricultural conservation practices in the United States: evidence from 35 years of quantitative literature. J. Soil Water Conserv. 74, 520-534. doi: 10.2489/jswc.74.5.520

Ranjan, P., Church, S. P., Floress, K., and Prokopy, L. S. (2019). Synthesizing conservation motivations and barriers: what have we learned from qualitative studies of farmers' behaviors in the United States? Soc. Nat. Resour. 32, 1171-1199. doi: 10.1080/08941920.2019.1648710

Reimer, A. (2013). Trends in U.S. Agricultural Conservation Programs. Harrisburg, PA: National Agricultural \& Rural Development Policy Center.

Reimer, A., Gramig, B., and Prokopy, L. (2013). Farmers and conservation programs: explaining differences in environmental quality incentives program applications between states. J. Soil Water Conserv. 68, 110-119. doi: 10.2489 /jswc.68.2.110
Reimer, A., and Prokopy, L. (2014). Farmer participation in U.S. farm bill conservation programs. Environ. Manage. 53, 318-332. doi: 10.1007/s00267-013-0184-8

Reimer, A. P., Weinkauf, D. K., and Prokopy, L. S. (2012). The influence of perceptions of practice characteristics: an examination of agricultural best management practice adoption in two indiana watersheds. J. Rural Stud. 28, 118-128. doi: 10.1016/j.jrurstud.2011. 09.005

Roesch-McNally, G., Arbuckle, J. G., and Tyndall, J. C. (2017). Soil as social-ecological feedback: examining the "ethic" of soil stewardship among corn belt farmers. Rural Sociol. 83, 145-173. doi: 10.1111/ruso. 12167

Rosman, H. (2015). The Farmer and Farm Networks: An Examination of Conservation Adoption in the U.S. Corn Belt. Iowa State University. Available online at: https://lib.dr.iastate.edu/cgi/viewcontent.cgi?article= 5613andcontext=etd (accessed August 01, 2019).

Rundquist, S., and Cox, C. (2016). Fooling Ourselves. Washington, DC: Environmental Working Group.

Stuart, D., Denny, R. C. H., Houser, M., Reimer, A. P., and Marquart-Pyatt, S. (2018). Farmer selection of sources of information for nitrogen management in the US midwest: implications for environmental programs. Land Use Policy 70, 289-297. doi: 10.1016/j.landusepol.2017.10.047

Ulrich-Schad, J. D., de Jalón, S. G., Babin, N., Pape, A., and Prokopy, L. S. (2017). Measuring and understanding agricultural producers' adoption of nutrient best management practices. J. Soil Water Conserv. 72, 506-518. doi: 10.2489 /jswc.72.5.506

USDA (2015). 2012 National Resources Inventory. Available online at: http://www. nrcs.usda.gov/technical/nri/12summary (accessed August 01, 2019).

USDA (2016). Conservation Stewardship Program Fact Sheet. Available online at: https://www.nrcs.usda.gov/wps/portal/nrcs/detailfull/national/programs/ financial/csp/?cid=nrcseprd1296837 (accessed January 08, 2019).

USDA (2017). 2017 Census of Agriculture. USDA National Agricultural Statistics Service. Available online at: www.nass.usda.gov/AgCensus (accessed August 01, 2019).

USDA (2018). Environmental Quality Incentives Program Fact Sheet. Available online at: https://www.nrcs.usda.gov/wps/portal/nrcs/detailfull/national/ programs/financial/csp/?cid=nrcseprd1296837 (accessed August 01, 2019).

USDA (2019). Conservation Reserve Program Fact Sheet. Available online at: https://www.nrcs.usda.gov/wps/portal/nrcs/detailfull/national/programs/ financial/csp/?cid=nrcseprd1296837 (accessed January 08, 2019).

Varble, S., Secchi, S., and Druschke, C. G. (2016). An examination of growing trends in land tenure and conservation practice adoption: results from a farmer survey in Iowa. Environ. Manage. 57, 318-330. doi: 10.1007/s00267-0150619-5

Conflict of Interest: The authors declare that the research was conducted in the absence of any commercial or financial relationships that could be construed as a potential conflict of interest.

Copyright (c) 2020 Medina, Isley and Arbuckle. This is an open-access article distributed under the terms of the Creative Commons Attribution License (CC BY). The use, distribution or reproduction in other forums is permitted, provided the original author(s) and the copyright owner(s) are credited and that the original publication in this journal is cited, in accordance with accepted academic practice. No use, distribution or reproduction is permitted which does not comply with these terms. 